\title{
Ellipsis
}

2014

\section{Other Cousins}

Jasmine Angel

University of New Orleans

Follow this and additional works at: https://scholarworks.uno.edu/ellipsis

Part of the Fiction Commons

\section{Recommended Citation}

Angel, Jasmine (2014) "Other Cousins," Ellipsis: Vol. 41 , Article 20.

DOI: https://doi.org/10.46428/ejail.41.20

Available at: https://scholarworks.uno.edu/ellipsis/vol41/iss1/20

This Fiction is brought to you for free and open access by the Department of English and Foreign Languages at ScholarWorks@UNO. It has been accepted for inclusion in Ellipsis by an authorized editor of ScholarWorks@UNO. For more information, please contact scholarworks@uno.edu. 


\title{
Other Cousins
}

\author{
Jasmine Angel
}

My family isn't exactly normal. I never met my daddy, and I don't know what he looks like. My momma will never talk to me about him. She just says not to worry about it. I asked her once if I was white because Marcus, Tori, and Devon said I looked it. And I looked in the mirror and saw myself. I've got really curly brown hair that goes down to the middle of my back and hazel eyes, and my skin color is...something that can't be found in a crayon box. It's somewhere between vanilla frappuccino and latte.

Marcus, Tori, and Devon-I call them my cousins, but we're not really related. They're my half-sister Ruby's cousins. They're not bad people, but it's hard being around them because they're just different. And I guess I've always felt like I didn't belong with them. Still, I think I can understand them now, when I didn't before. I even feel bad for Tori with what happened at Grandma Netta's last week, and now I think it might not have really been her fault.

Usually if I have to go over there, Ruby's there too because it's her grandma's house anyway. But Momma was at work, and Ruby wanted to go to the movies with her friends, so she couldn't babysit me. I didn't really need a babysitter because I'm eleven, but Momma doesn't let me stay home by myself.

Anyway, Ruby dropped me off, and Grandma Netta looked happy to see me. She gave me a big hug and two cheek kisses; the kind old people always give. She told me I was getting big, that my hair was longer and that I looked really pretty. Grandma Netta told me that it was a good day to come because Marcus and Devon were in the backyard and I should go play with them. I wasn't excited about playing with Marcus and Devon, but I agreed. There wasn't really anything else to do there.

Devon and Marcus were throwing rocks at the fence, making this clanging sound. The dog in the next yard was barking at them, but it was tied up too far away to reach them. The yard looked dirty, like always. There seemed to be more dried mud than there was grass, and on the left side, there was a big, dirty, red truck. It looked kinda familiar, but I wasn't sure who it was for. The paint was chipping, and the tires were covered in the same muck. I figured that the truck must be broken since it was left at Grandma Netta's.

"What you lookin' at Uncle Larry's truck for?" Marcus asked me.

"I don't know."

“How you don't know?" Devon asked with a smirk on his face. 
"Yeah, I thought you s'posed to be smart," Marcus said. I was annoyed. Marcus was being a jerk for no reason. And I really didn't feel like Devon, at the age of six, had the right to insult me.

"I was just looking at it," I said.

"What y'all doing?" This voice came from the back door, and we looked and saw that Tori had just walked through the raggedy screen door. My stomach started to churn because I really didn't want to see her. Last time I saw her, she had pulled my hair, and when I asked her to stop, she just pulled it more. I ended up crying, but I didn't tell Momma because I didn't want to be a wimp. She had five braids all over her hair-one in the front, two in the middle, and two in the back. They were dry and nappy. She was making an ugly scowling face and folding her ashy arms. I knew the day was about to get worse.

"We're getting in the truck," Marcus said.

"But it's dirty," I said.

"It's outside," Tori stated in an obvious manner as she rolled her eyes. She and Marcus helped Devon into the truck then they got in pretty effortlessly.

"You can't go anywhere in that truck," I said. "It doesn't work."

"I can fix it," Marcus said.

"Even if you could fix it, you can't drive."

"Yeah, I can." Marcus was being silly. I lifted an eyebrow in disbelief. "I can!"

"Whatever."

"So, are you going to get in the truck?" This was Tori now. She was sitting on the left side with Marcus and Devon facing each other on the right. I knew that there was no good reason to get in that truck because we couldn't go anywhere, but what else was I going to do? I was stuck with them and they called me a "scaredy cat," so I had to hop into the truck, making sure I didn't fall down in the process.

After awhile, we decided to play "Truth or Dare." Really, Marcus decided we'd play. I didn't understand why he always had to be in charge. He said it was because boys were smarter than girls and he was the oldest boy. He was eleven, like me and Tori. The first few turns were like this: Devon was dared to shut up for five minutes because he had started singing and banging on the truck in rhythm. Tori was dared to pull out a strand of hair, which she didn't, so Marcus punched her arm as punishment. Devon grabbed at one of her five braids and pulled out a barrette. She stared at him with evil eyes, and he backed into his corner, making a thudding noise against the floor and curling up his body. Then it was my turn.

"So, what should Lily have to do," Marcus asked.

"Cut her hair," Tori said. I cringed a little on the inside.

"No," I shouted. 
“Eat poop!" This was Devon's suggestion. Tori made a motion like cutting, pretending her middle and index fingers formed a pair of scissors.

"I'm not cutting my hair."

"Make her curse," Devon said much quieter than before. It looked like he was getting sleepy.

"Oh yeah, you don't curse," Marcus said, laughing at my ridiculousness. I backed into my little corner in the back of the truck. "Alright, say a curse word."

"I don't want to."

"It's a dare; you have to," Marcus said, like it was obvious.

"But I didn't even pick dare. I want truth."

"Just say the N-word. It's not even a real curse word."

"I don't say that word." I started to feel hot and uncomfortable.

"It's 'cause you white, ain't it?" I could practically feel the anger coming off Tori's face, but she wasn't red. She was too dark to turn red.

“No," I said, because it wasn't. I didn't know if I was white, but even if I wasn't it was wrong. It was an ugly word, always meant to hurt people. I was mad at her for saying that it wasn't a real curse word. It was just unfair.

"Why you don't say it if you ain't white?"

"It's too mean," I said and looked off to the side because I didn't want to look her in the eyes. She was a terrible person. But somebody made her that way. But I was so mad and I couldn't look at her.

"It's too mean," Tori said in a high-pitched voice.

"Are you white?" Marcus asked, but it didn't really seem mean. It seemed like he just wanted to know. Still, I felt under attack. My face felt hot, so I was probably turning red.

"I don't know!"

"So, you don't know?" Tori said.

"No, I don't," I replied. There was too much frustration and heat built up in the truck.

The sun was beating down on our heads, but we would have been sweating even if it was zero degrees outside.

"Then you gotta do another dare," Marcus said.

Tori made scissors with her hand again. I grabbed at my hair instantly. Tori seemed to be clenching her teeth, and she mumbled something about me. I knew she said "Lily" and something like "why curly hair." But Marcus let me off the hook and said that I could say another word besides the "N-word." But I didn't want to say anything. I didn't want to do anything for them anymore, not that I wanted to do much for them before that. I didn't care if they were going to punch me. But then Tori said she was going to punch me in the face. She had slit eyes, and she began moving toward me. Marcus told her to "chill out," but she cocked her fist back ready to hit me. I didn't have any time to run, and she was 
hovering over me. Her fist was almost to my face when I screamed.

"Don't touch me, you bitch!"

I felt like I was on fire because I had never said that to anyone before. And I knew it was bad. And I knew it was mean! And I wished that I could take it back because Tori had pulled back in shock. I knew she was furious now because I could hear her breathing. Even though it was terrible to say, I also knew it was true. Tori really was a bitch. Marcus was whooping for me until I felt Tori's hand whip straight across my face. It was hard. It was stinging, and I pushed her right back, but not as hard as I wanted to. I think I knew at least a little that she had a right to be mad at me, even if I had the right to be mad at her too. She was going to push me again, but Marcus stopped her. He yanked her by the arm and pushed her into the back of the truck. I heard her hit against the truck, nice and hard. Even though I was mad, I felt kinda bad for her. Maybe I had gone too far.

"Fuck you, Marcus! Why you always take her side!" Tori said. Her eyes were watery.

"Why you always act so stupid?" Marcus said.

"I ain't stupid!"

"You hit her! She did the dare!"

"Why you care that I hit her? You like white girls?" Tori rolled her eyes.

"Just be nice!"

"No!" Then Tori directed her attention to me, and I shook. I tried as hard as I possibly could to vanish even further into my space, though I knew I couldn't. She screamed hot dragon breath into my face and said, "Don't ever fucking talk to me like that again!"

"I won't," I said looking off to the side again. I couldn't make myself calm, though. It wasn't fair. I couldn't stand to be around her, but I knew I had gone too far with what I'd said. The word "bitch" was ringing in my ears. How would I like it if somebody said that word to me?

"Good. I want go home," Tori said. "I'm fucking pissed.” I just sat still in my corner while Marcus was waking up Devon. He was sleeping in the corner. while."

"Come on Lily," he said to me. "We probably gotta go inside in a li'l

It was starting to get dark. I got up and tried to help Devon get down, since he was smaller than everybody else. I picked him up and put him over the edge, telling him to hold on and I'd come over and guide him to the ground. His legs were resting on the tire, but Tori pushed me out of the way, and Devon's hand slipped. He fell back and hit the ground. He started screaming like crazy.

"Oh shit!" Marcus said. He, Tori, and I jumped out of the truck.

"We gotta tell Grandma Netta," I said.

"You ain't goin' tell on me," said Tori. 
"Yes I will," I said.

“Then I'm goin' tell Grandma Netta you called me a 'bitch'!”

I knew I was trapped. It wasn't fair. She cursed too, but she wouldn't care if I told on her for that. Grandma Netta would probably make us taste a bitter food and hold it in our mouths to remind us not to let anything nasty come out of them. But that wasn't a big deal. I didn't want Grandma Netta or my momma to be upset with me.

She looked at Marcus. "You ain't goin' tell neither."

"I ain't scared of you," he told her.

"You scared I'm goin' mess your white girl's face up," she said, pointing at me.

Marcus wasn't in charge anymore. Grandma Netta came running outside at the sound of Devon's screaming. There was a knot forming on his head. Grandma Netta rushed us inside and put a towel full of ice on Devon's head and told him to hold it there. Then she had him lay down on the big green sofa in the den, and he fell back to sleep. We all kind of stood around in the kitchen waiting and not saying anything. She walked away from Devon to us and said he was going to be okay, but she asked us what happened. We all said he fell. We didn't mention playing in the truck, but I think she knew we were leaving something out because she just said, "Mmm..hmm." I couldn't wait to go home.

First, Marcus and Devon left. Auntie Shawnee yelled at both of themMarcus for not watching his little brother and Devon for being stupid enough to practically "crack his skull open." With Devon gone, the couch was free, and Grandma Netta made me and Tori sit down while she went to get us some ice cream. We sat on opposite sides, and Tori folded her arms. I just sat still, waiting for everything to be over. I thought about apologizing, but she didn't deserve it after what she did to me, what she did to Devon.

Eventually, Uncle Tommy showed up. I held my breath because he always smelled like smoke. Tori looked up at her dad, still wearing the face she had been giving me all day. He told her to stop making "that face" because it made her look like "an ugly little bitch." I heard her whisper, "yes, Daddy." And then I really did want to apologize because I knew I had reminded her of her daddy. Grandma Netta came back just when Uncle Tommy was telling me I was pretty. She was frowning a little in Uncle Tommy's direction, but she smiled when she gave me my ice cream. She offered Tori her ice cream, but she wouldn't take it. Grandma Netta kissed her head and stared back at Uncle Tommy.

"Tommy," she said.

"What's up, Ms. Netta?"

"Be careful with Tori. She could get hurt."

"What she gone get hurt from?" 
"Just take care and God bless." She smiled and waved as they walked out the door.

I felt bad about it, and I kept feeling bad about it because I knew I was too mean to Tori. She was too mean to me too, but Momma says, "Two wrongs don't make a right." And I thought about it. I thought about how Uncle Tommy was mean to her and nice to me. And then I realized what she had said when she whispered in the truck. She didn't say, "why curly hair," she said, "white girl hair," and I knew she was jealous of me because she thought I was white. Usually when someone you don't like is jealous of you, you feel good because they deserve it, but maybe she didn't. I didn't want Tori to be jealous or hate me. I still don't. But it felt good to know why she was mad because then I knew that it wasn't my fault. It wasn't that I wasn't black enough that made her mad. It was that she couldn't be white, like she thought I was. 